\title{
PELATIHAN TEKNIK ECOPRINT UNTUK GURU PAUD
}

\author{
Vidya Kharishma1), Ulfa Septiana') \\ ${ }^{1}$ Fakultas Industri Kreatif dan Telematika, Universitas Trilogi \\ email: vidya.kharishma@trilogi.ac.id \\ ${ }^{2}$ Fakultas Industri Kreatif dan Telematika, Universitas Trilogi \\ email: ulfa.septiana@trilogi.ac.id
}

\begin{abstract}
One of early childhood education that can help children to convey ideas and imagination is art. Eco-print is a technique of art that utilizes natural materials as its ingredients. It has the potential to be a teaching material in early childhood education so children can appreciate and learns environmentally friendly art by harness the natural material around them. However, an eco-print lesson in early childhood education is still scarce due to the lack of teaching materials and the lack of the teacher's knowledge, specifically about eco-print techniques for early childhood education. This problem initiates the author to design training and teaching materials about eco-print techniques for teachers of early childhood education. Before the training conduct, there will be research preparation, analysis of participant needs, trial and error design of the eco print. After then, evaluation conduct between trainer and participant. Based on an analysis of participant needs, the best eco-print technique for this training is hammering, which is the most straightforward eco-print technique. However, the hammering technique, which usually uses a hammer, is replaced with pestle wood because it is safer for children. The implementation of training was carried successfully in the South Jakarta through the POSDAYA community. The result shows that teachers can accept the teaching materials due to the nature of its easy implementation, easily obtained material, and safety procedures.
\end{abstract}

Keywords: eco print, early childhood education, teacher environmentally friendly art.

\section{PENDAHULUAN}

Pendahuluan UU No. 20 tahun 2003 tentang perlindungan anak menyatakan pendidikan bukan saja hak setiap anak dalam rangka mengembangkan dirinya dengan kondisinya tetapi merupakan kewajiban semua pihak, termasuk orang tua, masyarakat, pemerintah. Maka dari itu, pengembangan pendidikan anak usia dini (PAUD) merupakan tanggung jawab bersama oleh semua pihak. Layanan pendidikan pada PAUD yaitu layanan dasar yang diselenggarakan di satuan PAUD untuk mengembangkan berbagai potensi anak yang mencakup nilai-nilai agama dan moral, fisik-motorik, kognitif, bahasa, sosial-emosional, dan seni (Direktorat Pembinaan Pendidikan Anak Usia Dini, 2015). Berdasarkan kerangka tersebut maka salah satu pendidikan yang dibutuhkan oleh PAUD yaitu seni.

Menurut Nancy Beal dan Gloria Bley, seni merupakan lakon, yang menolong anak-anak untuk memahami dunia mereka. Namun seni melebihi lakon yang akan membuat mereka mengekspresikan pengalaman-pengalaman dan fantasi-fantasi individu dengan cara-cara konkret dan spontan. Seni "mengundang" anak-anak untuk menyentuh dan melakukan eksperimen, mengeksplorasi dan mentransformasi segala hal yang anak-anak jumpai dalam kehidupan sehari-harinya (Tim Konsorsium Sertifikasi Guru, 2013). Karena itu, seni merupakan media yang dapat membantu anak usia dini untuk menyampaikan ide, gagasan, imajinasi, perasaan ataupun hal-hal lain yang biasanya tidak dapat mereka ungkapkan melalui kata-kata. Melalu seni anak-anak dapat belajar menciptakan suatu karya seni dan mengapresiasi keindahan seni.

Salah satu bentuk seni yang ditawarkan dalam pendidikan PAUD yaitu seni rupa atau menggambar. Media gambar adalah media yang berfungsi untuk menyampaikan pesan melalui gambar yang menyangkut indera penglihatan. Pesan yang disampaikan dituangkan melalui simbol-simbol komunikasi visual. Media gambar mempunyai tujuan untuk menarik perhatian, memperjelas materi, mengilustrasikan fakta dan informasi (Kusnasi dan Sujtipto, 2013). Unsur-unsur dasar seni rupa untuk mewujudkan sebuah karya senir rupa terdiri dari garis, bentuk, tekstur, ruang, ukuran dan warna. Bekerja dengan material seni menawarkan anak-anak kesempatan untuk bereksperimen dengan warna, bentuk, rancangan, dan tektur. Menggunakan material seni seperti lukisan, lilin, spidol, krayon, kanji dari 
tepung jagung, dan susunan benda-benda potongan kertas, dapat membuat anak-anak mengekspresikan ide dan perasaan pribadi mereka (Sophya, 2015).

Teknik eco-print adalah salah satu bentuk seni rupa yang memanfaatkan bahan alam sebagai bahannya. Umumnya teknik eco-print diaplikasikan pada kain yang menjadikannya produk kriya. Penggunaan zat alami yang umum digunakan, berasal dari berbagai bagiandari tumbuhan, di antaranya menggunakan bahan dari bagian kulit pohon seperti tingi, kayumanis, mahoni; bagian daun seperti jati, teh, dan indigofera; bagian daging maupun kulit buah seperti manggis, buah naga, mangga; serta bagian akar seperti kunyit. Pembelajaran dengan teknik ecoprint dapat menjadi contoh pembelajaran multi disipliner yang memadupadankan pembelaja-ran seni dengan pembelajaran mengenai lingkungan. Suwardi mengatakan, alat peraga pendidikan akan lebih menarik apabila disajikan dengan menarik, sehingga pendidik yang dapat mengoptimalkan kemampuan untuk membuat dan memanfaatkan alat peraga edukatif yang efektif dan efesien khususnya diberikan pada anak usia dini, selain daripada itu dengan memiliki kemampuan memadukan seluruh sumber daya dan dana yang potensial dengan terfokus anak usia dini dengan memanfaatkan lingkungan sekitar anak (Suwardi, 2011). Dengan pembelajaran teknik eco-print, anak-anak usia dini dapat memahami dan mengapresiani seni yang ramah lingkungan dengan memanfaatkan alam sekitarnya.

Workshop-workshop batik eco-print sudah cukup banyak dilaksanakan di kalangan masyarakat. Contohnya Workshop batik eco-print di Selopamioro Imogiri Bantul oleh PututArdianto (33) yang diikuti berbagai kalangan, dari mulai ibu rumah tangga, guru, karyawan, hingga mahasiswa. Salah satu pesertanya pun memiliki ide untuk mengajarkan teknik tersebut untuk anak-anak PAUD sehingga bisa melatih motorik anak dan belajar mengenal warna (Chasanah, 2017). Namun, sampai saat ini penulis belum menemukan workshop pembelajaran teknik eco-print yang ditujukan untuk PAUD beserta bahan ajarnya. Selain itu juga, belum ditemukan pembelajaran teknik eco-print pada PAUD. Hal ini, menggambarkan kurangnya pengetahuan guru-guru PAUD mengenai teknik ecoprint.

Kurangnya bahan ajar mengenai teknik ecoprint untuk PAUD dan kurangnya pengetahuan guruguru PAUD mengenai teknik eco-print menginisiasi penulis untuk merancangan pelatihan dan membuat bahan ajar mengenai teknik eco-print untuk guru-guru PAUD. Untuk merealisasikan pelatihan ini maka pengabdian akan dilaksanakan di dekat lokasi penulis yaitu daerah Jakarta Selatan. Pelatihan akan ditujukan untuk guru-guru PAUD di sekitar Jakarta Selatan melalui forum POSDAYA.

\section{KAJIAN LITERATUR}

Ecoprint adalah satu cara menghias kain dengan memanfaatkan berbagai tumbuhan dengan memanfaatkan warna-warna alaminya. Terdapat beberapa cara membuat eco-print, dua cara tersebut adalah:

1. Teknik gulung (bundles)

Teknik gulung (bundles), dilakukan dengan cara menyusun bahan-bahan alam, seperti dedaunan dan bunga sesuai dengan pola yang diinginkan di atas kain. Setelah itu kain digulung dengan rapat lalu diikatnya, dan dikukus hingga keluar warna dari bahan-bahan alami tersebut (Irianingsih, 2018).

2. Teknik pukul (hammering)

Teknik palu (hammering), dilakukan dengan menyusun dedaunan dan bunga sesuai dengan pola yang diinginkan di atas setengah bagian kain, kemudian kain tersebut dilipat dan bagian yang terdapat dedaunan dan bunga dipukul-pukul hingga keluar warnanya, kemudian dikukus (Irianingsih, 2018).

3. Solar Dye

Solar dye, dilakukan dengan cara menyusun bahan-bahan alam di atas kain, kain digulung dengan rapat lalu diikat dan disimpan dalam botol yang berisi air dan bahan-bahan alami lainnya, lalu dijemur selama setidaknya 1 hari (Barendregt \& Jaffe, 2014).

Kain harus terlebih dahulu diolah atau dimordant agar lapisan lilin maupun pemutih pada kain luruh/terlepas, dan warna-warna pada tumbuhan mudah diserap

1. Scouring

Kain direndam pada larutan TRO (bisa diganti dengan deterjen) dengan takaran 1 sendok makan dalam 5 liter air selama 30 menit - 1 jam, kemudian bilas.

2. Mordant

Kain direndam pada larutan yang berisi tawas $( \pm$ $1 / 2$ sendok makan) dan soda ash ( $\pm 1 / 4$ sendok makan) dalam 5 liter air selama 1 jam - 1 malam, kemudian bilas dan keringkan.

Setelah pola yang diinginkan tercetak di kain, kain dibersihkan dari sisa daun yang menempel dan 
dilakukan proses fiksasi. Proses fiksasi dilakukan dengan merendam kain yang sudah dibatik dengan air campuran tawas. Proses ini berguna untuk mengikat motif dan warna yang sudah tercetak di atas kain.

Jenis tumbuhan yang cocok untuk teknik ecoprint adalah jenis tumbuhan yang ketika diremas dapat mengeluarkan warna dan aroma, jenis daun yang tidak terlalu tua, atau daun yang gugur namun yang warnanya masih muda

\section{METODE PELAKSANAAN PENGABDIAN}

Metode pelaksanaan program PKM ini adalah sebagai berikut:

1. Persiapan pelaksanaan pelatihan

Pada tahap ini tim melakukan pendataan kebutuhan-kebutuhan pelatihan dengan melakukan brainstroming dan diskusi langsung. Tahapan pelaksanaannya meliputi diskusi dan brainstorming dengan tim untuk menghasilkan desain ecoprint yang akan diaplikasikan oleh mitra pelatihan dan pendataan bahan yang diperlukan untuk pembuatan eco-print.

2. Analisis kebutuhan mitra

Pada tahap ini tim melakukan analisis mengenai kebutuhan mitra. Tahapan pelaksanaannya meliputi menganalisis kebutuhan mitra terkait pembelajaran eco print dan menganalisis perancangan desain eco-print yang akan diaplikasikan oleh mitra pada saat pelatihan.

3. Perancangan eco-print

Pada tahap ini tim membuat rancangan eco-print yang akan diaplikasikan oleh mitra. Tahapan pelaksanaannya meliputi perancangan motif ecoprint dan pembelian bahan untuk pelatihan ecoprint.

4. Pelatihan materi eco-print

Pada tahap ini tim memberikan pengajaran mengenai eco-print pada mitra. Tahapan pelaksanaannya meliputi pembuatan materi pembuatan eco-print bagi mitra dan pelatihan pembelajaran eco-print di Universitas Trilogi Jakarta.

5. Evaluasi

Pada tahap ini tim akan melakukan evaluasi dan mendengarkan feedback dari mitra. Tahapan pelaksanaannya meliputi berdiskusi dengan mitra untuk mendapatkan feedback hasil pelatihan ecoprint dan tim merumuskan kesimpulan dari hasil akhir pelatihan eco-print.

\section{HASIL DAN PEMBAHASAN}

\section{IV.1. Analisis Kebutuhan Mitra}

Teknik pukul (hammering), merupakan salah satu metode dalam pembuatan eco-print yang dilakukan dengan menyusun dedaunan dan bunga sesuai dengan pola yang diinginkan di atas setengah bagian kain, kemudian kain tersebut dilipat dan bagian yang terdapat dedaunan dan bunga dipukul-pukul hingga keluar warnanya, kemudian dikukus (Irianingsih, 2018). Dalam teknik pukul, alat yang digunakan biasanya palu. Pada pelatihan eco-print ini alat pukulnya diganti dari palu menjadi ulekan kayu. Penggantian alat menjadi ulekan kayu ini berfungsi untuk menjaga keamanan anak PAUD, ketika para gurun mentransfer ilmu eco-print kepada mereka. Palu memiliki sifat berat dan tajam. Karakteristik palu ini akan dapat membahayakan dan memberat-kan jika digunakan oleh anak PAUD. Sementara ulekan kayu memiliki karakter tumpul dan ringan.

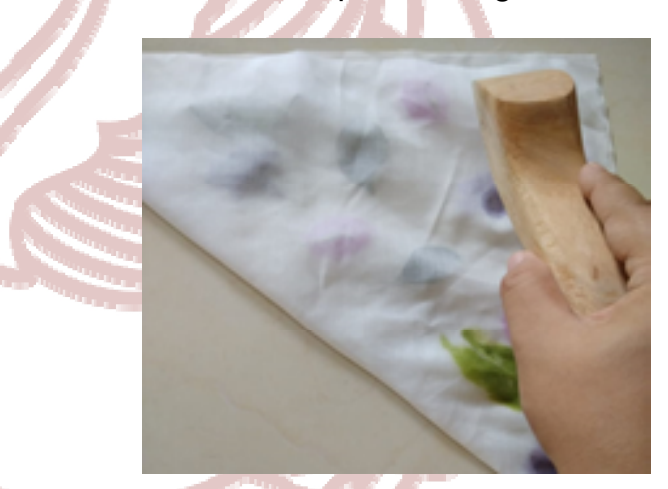

Gambar 1. Teknik pukul dengan ulekan kayu (Sumber: Kharishma, 2019)

\section{IV.2. Perancangan Materi Pengabdian}

Sebelum merancang materi PKM, penulis melakukan uji coba dalam membuat eco-print dengan teknik pukul dan menggunakan ulekan. Berikut ini adalah hasil uji coba yang akan digunakan untuk materi pelatihan.

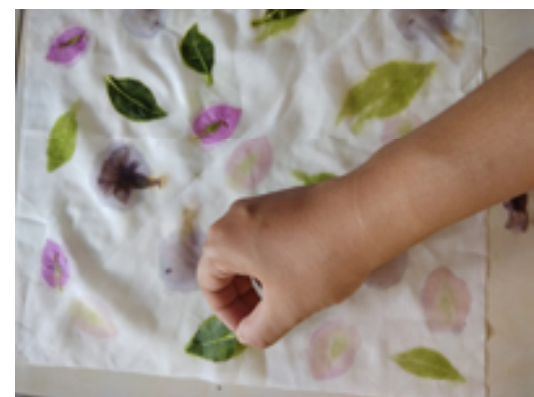

Gambar 2. Hasil uji coba (Sumber: Kharishma, 2019) 
Hasil uji coba ini lalu menjadi bahan materi untuk pelaksanaan PKM. Pada pelatihan PKM ini, materi akan diberikan dalam dua format yaitu, (1) presentasi secara langsung yang didukung dengan power point dan (2) handout yang akan dibagikan pada peserta PKM. Handout dicetak di kertas HVS 80 gram dengan ukuran A5. Materi yang diberikan yaitu (1) pengertian umum mengenai eco-print, (2) proses mordant kain, (3) jenis tumbuhan yang cocok untuk teknik pukul eco-print, (4) peralatan dan bahan, (5) langkahlangkah eco-print dengan teknik pukul.

\section{IV.3. Pelaksanaan Pengabdian}

Pengabdian berupa pelatihan eco-print untuk Guru PAUD ini telah diselenggarakan pada hari Selasa, tanggal 6 November 2018 di Ruang 104, Universitas Trilogi. Pelatihan ini dihadiri oleh 22 orang guru PAUD.Pada tahap pertama, peserta akan terlebih dahulu diberikan materi dan instruksi mengenai pembuatan eco-print dengan teknik pukul. Bersamaan dengan ini peserta juga akan dibagikan alat dan bahan yang akan digunakan untuk praktek pembuatan ecoprint. Setelah presentasi, peserta akan diberikan waktu untuk tanya jawab dan diskusi sebelum praktik pembuatan eco-print.

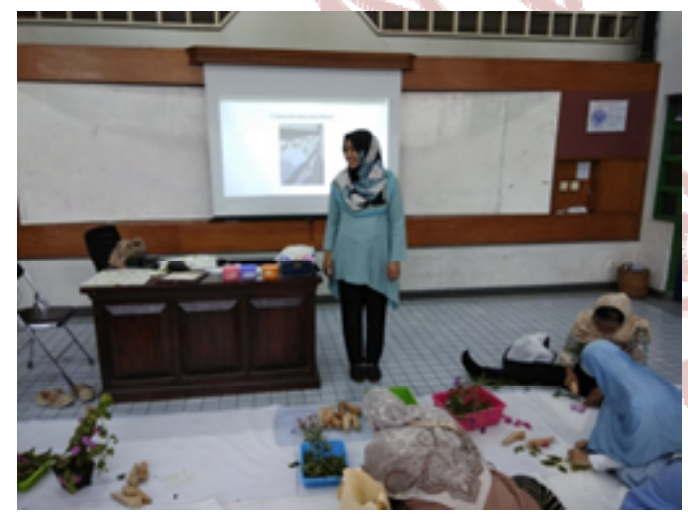

Gambar 3. Presentasi teknik eco-print (Sumber: Kharishma, 2019)

Hal pertama yang dilakukan oleh peserta dalam memulai pembuatan eco-print dengan teknik pukul adalah menyusun bunga dan daun dalam bentangan kain yang sudah dibagikan. Pada tahap ini, peserta dapat berkreasi secara bebas seusia dengan penilaian estetika masing-masing. Setelah disusun lalu peserta menutup susunan daun dan bunga tersebut dengan selembar kain lagi. Setelah itu peserta mulai mukul-mukul tanaman yang berada di antara dua kain.

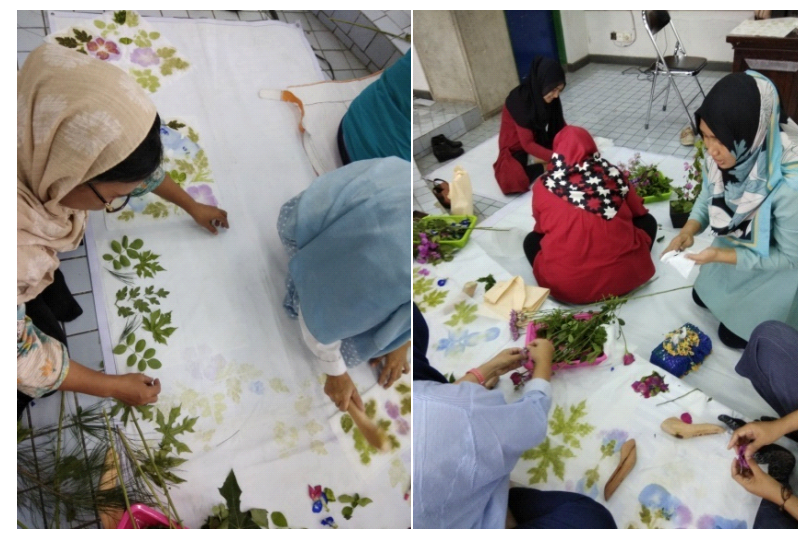

Gambar 4. Proses penyusunan tanaman pada kain (Sumber: Kharishma, 2019)

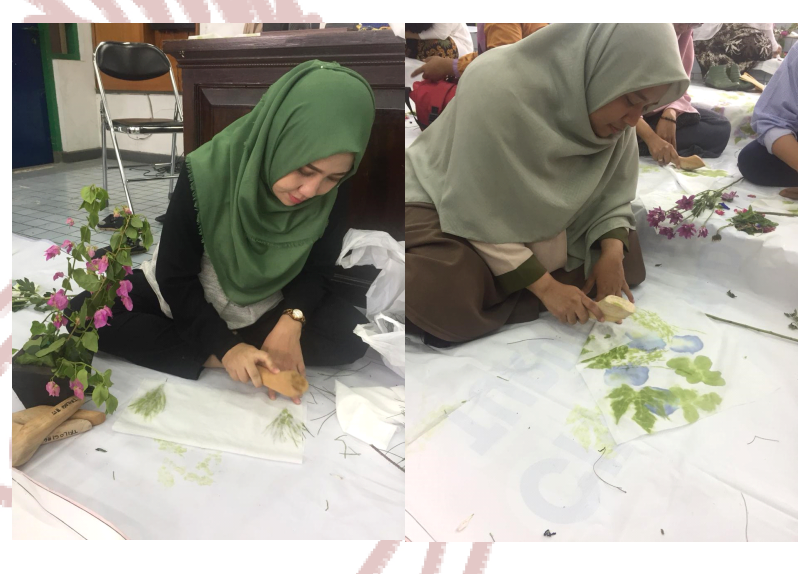

Gambar 5. Proses pemukulan tanaman pada kain (Sumber: Kharishma, 2019)

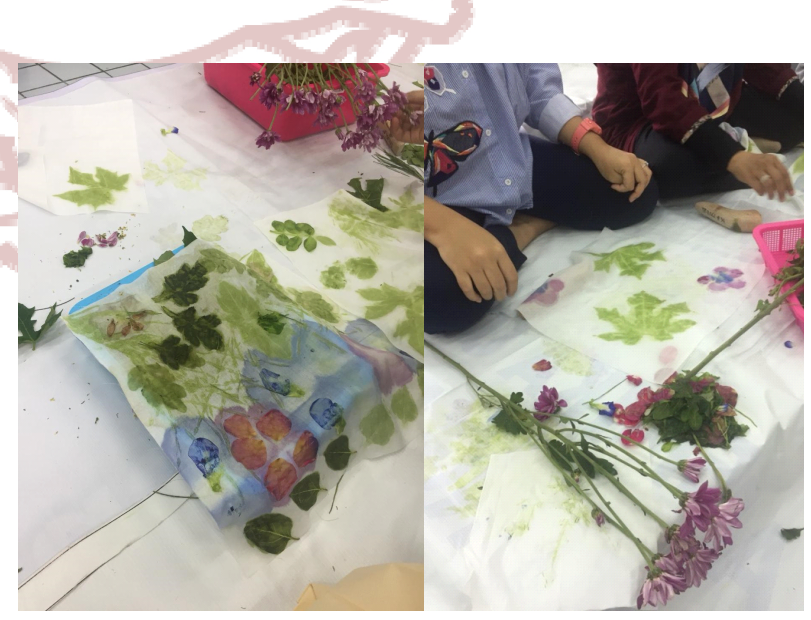

Gambar 6. Hasil cetakan setelah proses pemukulan tanaman pada kain (Sumber: Kharishma, 2019).

Setelah tanaman tercetak dengan jelas pada kain, lalu peserta harus melepaskan sisa-sia tanaman yang mempel pada kain. Setelah kain bersih dari tanaman, maka kain akan direndam pada larutan fiksasi selama 30 menit. 


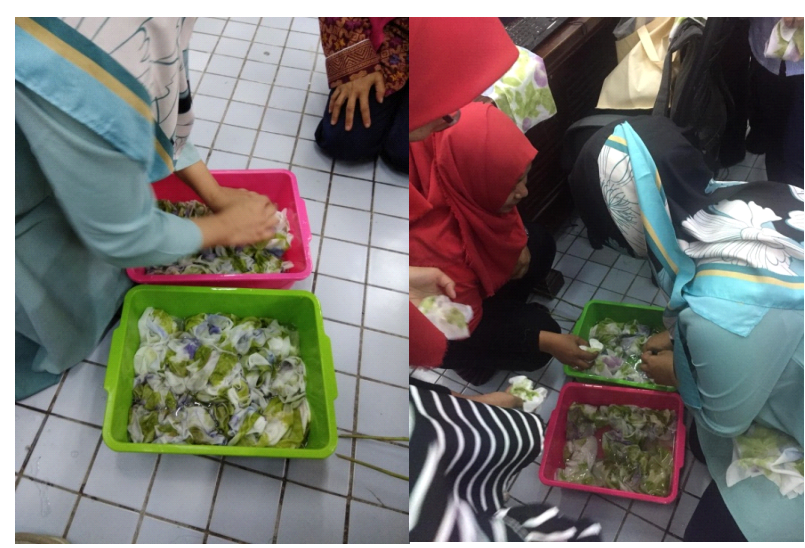

Gambar 6. Proses penyusunan dan pemukulan tanaman pada kain (Sumber: Kharishma, 2019)

Setelah kain direndam selama 30 menit maka kain akan dijemur di lapangan. Waktu proses penjemuran tentatif, tergantung lokasi dan kadar sinar matahari ketika proses penjemuran. Pada proses ini mulai terlihat penurunan dan perubahan warna dari proses awal ketika dipukul. Pada hasil kegiatan pengabdian ini, cetakan yang menggunakan bagian daun terlihat lebih jelas dan tahan dibandingkan cetakan dari bagian bunga.

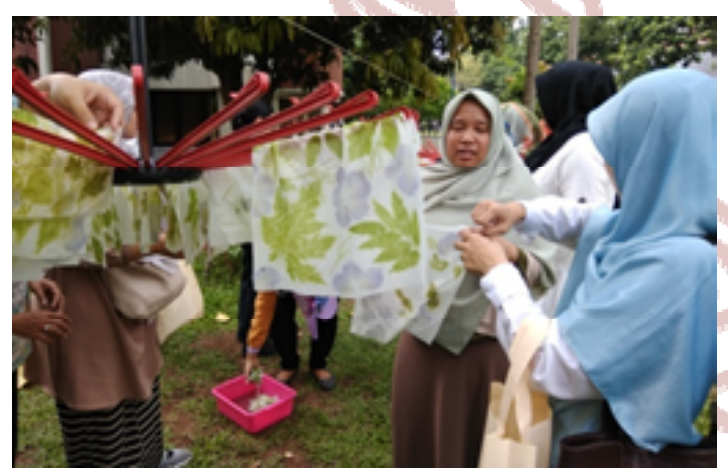

Gambar 7. Proses penjemuran kain (Sumber: Kharishma, 2019)

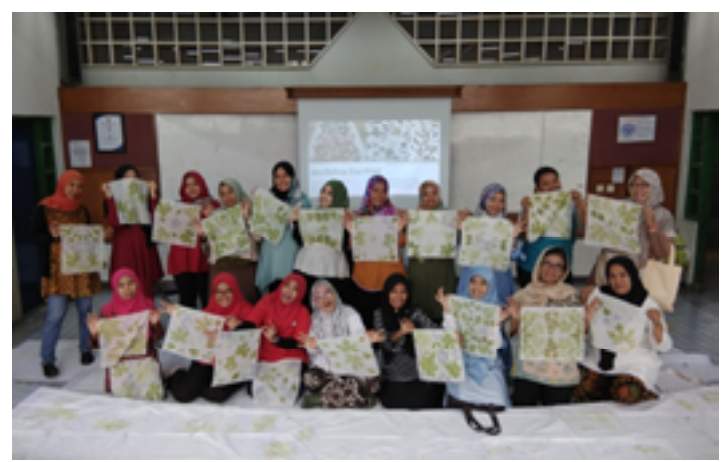

Gambar 8. Hasil karya peserta PKM eco-print (Sumber: Kharishma, 2019)

\section{KESIMPULAN}

Pelatihan teknik eco-print yang untuk murid PAUD dianjurkan menggunakan teknik pukul dengan ulekan kayu. Teknik pukul merupakan teknik ecoprint yang paling mudah dilakukan sehingga dapat cepat dipahami untuk murid PAUD. Alat yang untuk teknik ini digunakan dari palu menjadi ulekan kayu karena lebih aman digunakan untuk anak-anak usia dini. Daun sebagai bahan lebih baik digunakan dari bunga karena pada umumnya hasil cetakan bagian daun terlihat lebih jelas dan tahan lama dibandingkan cetakan dari bagian bunga.

\section{DAFTAR PUSTAKA}

Barendregt, Bart \& Jaffe, Rivke. (2014). The Global Rice of Eco-Chic: Green Consumption. London:Bloomsbury Publishing Plc.

Chasanah, Amalia Mitfathul. 2017. "Batik Eco-print, yang sederhana jadi barang mahal". Diakses dari http://wargajogia.net/bisnis/batik-ecoprint-yang-sederhana-jadi-barangmahal.html

Direktorat Pembinaan Pendidikan Anak Usia Dini. (2015). Petunjuk Teknik Penyelenggaraan PAUD Holistik Integratif di Satuan PAUD. Diakses dari http://paud.kemdikbud.go.id/ wpcontent/uploads/2016/04/Juknis-PAUDHI.pdf

Irianingsih, Nining. (2018). Eco Print Motif Kain dari Daun dan Bunga. Jakarta: Gramedia

Kusnasi, Cecep dan Sujtipto, Bambang. (2013). Media Pembelajaran Manual dan Digital. Bogor: Ghalia Indonesia.

Sophya, Ida Vera. (2015). Model pembelajaran Kesenian di PAUD Ya Ummi Fat Desa Bermi Kecamatan Mijen Kabupaten Demak. Jurnal ThufuLA: Jurnal Inovasi Pendidikan Islam Anak Usia Dini, 3(1), 79-102

Suwardi. (2011). Efektifitas Media Pembelajaran bagi Pendidikan PAUD yang Ramah Lingkungan. Jurnal Al-Azhar Indonesia series humaniora, 1(2), 72-77.

Tim Konsorsium Sertifikasi Guru. (2013). Modul PLPG: Pendidikan Anak Usia Dini. Jakarta:Universitas Negeri Jakarta Press 